\title{
MASCULINIDADE RELIGIOSA, PATRIARCADO E FEMINICÍDIO: REVENDO O CASO DE MÃE OBASSI ${ }^{1}$
}

\author{
Joanice Conceição UNILAB -CE \\ Coordenadora do Grupo de Estudos e Pesquisas AZÂNIA
}

\section{INTRODUÇÃO}

No presente capítulo intentamos discorrer sobre as opressões sofridas pelas mulheres ${ }^{4}$, especialmente nos espaços considerados sagrados. Entretanto, fazem-se necessárias algumas explicações no que tange a conceitos caros à tal discussão. Na verdade, estamos a revisitá-los. Visto que diversos momentos, ainda que de forma outra, já os tenhamos utilizado para embasar escritos acadêmicos. Porém, o fazemos por entender que os conceitos não são estanques, eles aderem às mudanças que ocorrem nos relevos culturais em que se aplicam.

$O$ primeiro a ser abordado é o conceito de patriarcado. Muito bem trabalhado pela pensadora Saffioti (2004). Decerto, determinados leitores poderiam se perguntar: por que utilizar um conceito tão antigo, aparentemente esquecido nas grandes discussões sobre gêneros hodiernamente? À priori, podemos dizer que ao usar esse conceito buscamos refletir sobre a maneira como o patriarcado, ainda hoje, fornece bases para estruturar as opressões/violências direcionadas às mulheres; violências vistas como corriqueiras, quase banalizadas ao serem difundidas nos meios de comunicação. Através da análise do conceito de patriarcado, almejamos verificar como as atitudes oriundas desse sistema estão presentes nos espaços religiosos.

\footnotetext{
${ }^{1}$ DOI 10.29388/978-65-86678-76-5-f.61-84

${ }^{2}$ Doutora e Mestre em Ciências Sociais/Antropologia; Professora do Colegiado em Antropologia e BHU da UNILAB-CE

${ }^{3}$ Universidade da Integração Internacional da Lusofonia Afro-Brasileira.

${ }^{4}$ Ainda que o conceito "mulher" seja amplamente criticado por grande parte das feministas africanas, sobretudo, por aquelas que estão ao Sul do continente, opto neste artigo pela sua utilização por entender que as mulheres aqui referidas, mesmo que estejam inseridas numa sociedade ocidental não deixo de observar que os contextos em que essas mulheres estão imersas possuem também valores simbólicos e materiais que estão ancorados em margens africanas. Oyèrónké Oyěwùmi (2004) nos diz que a mulher na teoria feminista é uma esposa, isto é, a metade de um casal em uma família nuclear, que esquece dos diversos arranjos familiares. Não obstante, ao alerta das autoras já mencionadas, utilizo o termo esforçando-me para trazer as especificidades que envolvem as mulheres aqui referidas.
} 
Outra categoria fulcral neste texto é a das masculinidades ${ }^{5}$ que ganhou destaques nos estudos acadêmicos, porém sempre se manteve aliada às opressões/violências sexistas e misóginas praticadas contra as mulheres. A masculinidade tratada aqui é aquela que se assemelha à hegemônica, mas, por outro lado, revela-se divergente, uma vez que é mascarada pela sacralidade da religião. Seria, por assim dizer, uma masculinidade religiosa ${ }^{6}$, onde não haveria, aparentemente, um dominador em oposição a uma massa dominada, posto que o discurso de igualdade entre as pessoas é o axioma dos espaços religiosos.

Outro ponto a ser abordado diz respeito ao conceito de violência associada à raça e a religião. A escolha deste construto, justifica-se por considerarmos que as opressões/violências sofridas pelas mulheres não são resultantes de um único vetor, ao contrário, se interseccionam. Segundo Girard (2008), a violência associada ao sagrado tem suas bases no "desejo mimético" que um indivíduo possui naquilo que pertence ao outro. Isto pode derivar na rivalidade, na raiva e, consequentemente, no aumento dos conflitos e nas separações que alimentam as violências, tal como ocorre nos espaços sociais. $O$ aspecto apontado por Girard coaduna com a genealogia do mito da inveja masculina descrita por Saffioti na obra "Violência de Gênero: Poder e Impotência" (1995) ${ }^{7}$.

O que queremos realçar com isto é que as opressões/violências são ainda maiores quando a mulher é negra, pobre, periférica. As violências que trazemos para a discussão são aquelas que não se associam, tão-somente, aos danos à integridade física, sexual ou moral. Referimo-nos

\footnotetext{
${ }^{5}$ Vários estudos atestam a capacidade de variação da masculinidade e feminilidade em diferentes perspectivas, levando-nos a dizer que nem todos os tipos de mulheres estão contemplados no interior das ondas do feminismo, ao contrário, o foco está nas realidades das mulheres brancas europeias e estadunidenses. De igual modo, a masculinidade se apresenta atrelada a contextos díspares, racializado, classificado e não cisgêneros. Logo, nem todos os homens possuem a mesma masculinidade que um homem branco cisgênero, heteronormativo, rico. A branquitude orquestra um modo de vida para o homem negro que é delineado a partir de no mínimo dois eixos: classe, raça. Contudo, não quero aqui tirar das costas do homem negro as opressões que ele também pode infringir às mulheres; aliás, coloco em tela as violências praticadas dentro dos espaços religiosos, com maior enfoque para o candomblé. Para ampliar a discussão, consultar Connell (2010), Conceição (2017), Oliveira (2004), dentre outros.

${ }^{6}$ Conceituo aqui, momentaneamente, a Masculinidade Religiosa como a opressão/ violência praticada contra às mulheres e pessoas consideradas subalternas no interior das instituições religiosas, tendo em vista que os símbolos religiosos funcionam como sintetizadores do ethos de um povo. (GEERTZ, 1988). A categoria mencionada encontra-se em processo de formulação, porém, expressa a ação que busco ressaltar neste momento.
}

${ }^{7}$ Sobre o mito a que se refere Saffioti (2004, p. 33). 
também às violências simbólicas, por acreditar que todas ou quase todas as formas das opressões dirigidas às mulheres estejam subliminarmente nas ações sutis que as querem subordinadas. São violências quase imperceptíveis, "suaves", quase sempre invisíveis a quem dela é vítima. Violências que se exercem essencialmente por vias simbólicas (BOURDIEU, 2010). Consideramos, pois, que a violência está fortemente afirmada na negação da humanidade do outro no jogo da alteridade.

Não obstante, toda carga negativa que a população brasileira herdou do processo colonial, sobretudo o racismo, o classismo e o heterossexismo, ainda assim, em determinados espaços tradicionais das culturas africanas as mulheres negras encontram brechas para transgredirem a ordem vigente. Conquanto, elas ainda lutem contra as epistemes ocidentais, na manipulação da mitologia e saberes africanos, a fim de legitimar a proeminência masculina.

Autoridades femininas reais, como Oba foram desfeitas, traduzidas somente para majestade ancestral masculina. Sistemas de conhecimentos foram ignorados, com vistas, por exemplo, à negação de experiências marcadas pela maternidade, casamento e família, desenraizadas do modelo nuclear ocidental, razão da pesquisadora Oyèrónké Oyěwùmi mencionar gênero como categoria historicamente recente para o povo iorubá, com aplicação particular da colonização europeia e valor epistêmico colonial. (AKOTIRENE, 2019, p. 81).

O excerto acima mostra como o conhecimento também é manipulado para favorecer a hegemonia masculina. Sabemos que as primeiras versões e traduções da mitologia africana foram feitas por homens brancos, logo as qualidades femininas muitas vezes foram suprimidas. Percebemos, contudo, que a maternidade sempre foi ressaltada.

A opção de associar opressão/violência à questão racial se deve ao fato de que as pessoas em seus comportamentos racistas acreditam na falta de humanidade do negro ou da negra, como aponta Silva (2017), portanto, a inexistência de humanidade faz com que essa opressão/violência seja ampliada e naturalizada. Ao adicionar a categoria religião ao binômio violência-raça acreditamos que essa junção pode ser um dos alicerces para pensar a maneira como a religião contribui para a opressão/ violência. Visto que na visão ocidental, Deus é um ser superior, homem, heterossexual e branco. Nestes termos, sabemos o quanto essas características pesam no cotidiano da população negra. De maneira especial, ressaltamos, para a mulher negra praticante das religiões de matrizes africanas, posto que grande parte dos cristãos acreditam que tais religiões, seriam "amaldiçoadas", na medida em que são originárias de um de con- 
tinente igualmente "amaldiçoado" (CONCEIÇÃO, 2018). Logo, o racismo é uma das engrenagens da opressão/violência. Dessa forma, a humanização não é uma característica atribuída às pessoas negras por parte de racistas.

Uma crença mais do que qualquer outra é responsável pelo massacre de milhões de seres humanos ao longo da história: é a crença de que aqueles que não comungam da minha fé - ou da minha raça ou da minha ideologia - não compartilham da minha humanidade. (BERLIN, 2009, p. 175).

A citação acima ressalta uma das origens do racismo e outros males que atingem os indivíduos, sobremaneira às mulheres. A negação da crença, da heterogeneidade dos povos pode fazer muitas vítimas. A religião passaria a ser legitimadora da opressão/violência, quando delas comunga e defende, como pode ser visto no período escravista do Brasil.

\section{O PATRIARCADO E A MASCULINIDADE: UM DUPLO PERIGO}

Nesta seção, abordaremos a relação entre patriarcado e a masculinidade por acreditarmos que existe uma intersecção direta entre as duas categorias. Todavia, é preciso, desde logo, indagar-nos sobre o porquê da escolha do conceito de masculinidade no espaço religioso, mesmo quando o protagonismo é de mulher. Vale salientar que, embora, o espaço tenha por excelência a liderança feminina, a sociedade mais ampla, erroneamente, reitera e afirma as ações patriarcais no interior desses espaços.

A masculinidade utilizada aqui não será vista como algo inerente ao masculino, assim como a feminilidade não está unicamente relacionada à mulher. Neste sentido, rompemos com a dicotomia colocada entre sexo e gênero. Aqui, a masculinidade ganha contornos diferentes a depender da classe, da raça, lugares e vivências sexuais. Portanto, refutamos o determinismo biológico (SCOTT, 1990). Particularmente, falamos de uma categoria que reflete uma espécie de poder que se assenta na perspectiva servindo-se do patriarcado para a efetivação da dominação masculina. Aquela associada à virilidade como sinônimo do poder, que subordina os demais, pois os julgam como inferiores e neste rol inclui especialmente as mulheres. Especificamente, referimo-nos à masculinidade, cujo exercício é feito por um homem branco, homossexual contra uma mulher negra no espaço e no exercício religioso.

Em contrapartida, as masculinidades tidas como subalternas quando confrontadas com a masculinidade hegemônica veem-se em desvantagem. Ou seja, quem subalterniza também é subalternizado. Posto que, o homem branco, rico, cisgênero e provedor de família é alçado a uma suposta superioridade, segundo a masculinidade hegemônica. É nes- 
te campo em que se insere a ligação entre patriarcado, masculinidade negra, violência e religião. Como alerta a epígrafe:

Na minha opinião "patriarcado" será a definição de uma ordem de gênero específica na qual a masculinidade hegemónica define a inferioridade do feminino e das masculinidades subordinadas. É a lenta degradação e contestação do patriarcado que tem permitido pensá-lo - ou seja, estamos a viver um período de transição histórica, de transformação da hegemonia, em que os conflitos, "ruídos" e disputas que sempre existiram se tornam mais audíveis e perturbadores. (ALMEIDA, 1996, p. 4).

O raciocínio acima, elaborado em 1996, já prenunciava as transformações ou visibilidades que tangiam as questões relativas à hegemonia da masculinidade, a ele, acrescentamos as alterações ocorridas no interior das religiões de matrizes africanas, tendo em vista a proeminência feminina quando da fundação das primeiras comunidades religiosas em solo brasileiro. Com isso, não nos furtamos a ideia da existência de práticas religiosas desse segmento étnico realizadas por homens, no entanto, é com as mulheres que esse viés religioso ganha notoriedade e visibilidade (LANDES, 1967; REIS, 2003; BRAGA, 2014).

$O$ patriarcado sempre esteve de mãos dadas à masculinidade hegemônica. Quando se olha para as religiões de outras matrizes no Brasil entendemos que as cosmovisões que orientam as concepções acerca do masculino e feminino passam por outras paragens que não unicamente a ocidental. Por conseguinte, não se deve perder de vista que essas religiões, uma vez inseridas em terrenos ocidentais, logram destes determinados valores que orientam suas condutas. Logo, padecem do mesmo modo das opressões patriarcais na medida que delas partilham.

O patriarcado é um sistema político modelador da cultura e dominação masculina, especialmente contra as mulheres. É reforçado pela religião e família nuclear que impõem papéis de gênero desde a infância baseado em identidades binárias, informadas pela noção de homem e mulher biológicos, sendo as pessoas cisgêneras aquelas não cabíveis necessariamente nas masculinidades $\mathrm{e}$ feminilidades duais hegemônicas (AKOTIRENE, 2019, p. 119).

A autora mostra como as ações do patriarcado encontram apoio na divisão desigual dos papéis distribuídos entre homens e mulheres, reforçando como a família nuclear e a religião contribuem para avigorar, ainda mais, as opressões/violências dentro de grupos de mesmos pares. Nesta mesma perspectiva, chama a atenção o fato do saber científico, em grande medida, reforçar as identidades masculinas e femininas a partir diferenças biológicas, de modo que estas criam também outras diferenças. 
Ainda que tenha havido avanços, em campos como a psicologia, história e antropologia, o gênero persiste como "uma categoria útil" para classificar homens e mulheres, a partir dos papeis sociais que lhes são conferidos (SCOTT, 1990). Percebemos que as religiões ainda não trabalham de forma aprofundada a diversidade dos gêneros, ao contrário, operam com a lógica binária. Embora não seja o tema deste artigo, temos consciência que esse é um debate a ser encarado pelas religiões, especialmente as de matrizes africanas, que são tidas como as mais respeitosas para com pessoas não-cisgêneras.

Pateman (1993 apud SAFFIOTI, 2004) argumenta que o patriarcado antecede à masculinidade, já que na base do pacto que orienta as relações sociais, traz implicitamente um contrato que regula a convenção de liberdade para os homens e a sujeição e a privação para as mulheres. Partindo das observações feitas e com base nas entrevistas realizadas, formulamos duas questões-problema: (i) Em que medida o patriarcado se coloca hierarquicamente acima da masculinidade hegemônica dentro da esfera religiosa? A outra questão que está intrinsecamente relacionada à primeira é, (ii) Será que existe uma categoria que dê conta de toda polissemia que o conceito de patriarcado explicita ao fazer referência à sujeição da mulher?

Para a primeira questão podemos supor que, assim como as instâncias religiosas integram as estruturas que compõem a sociedade e, como parte dessas estruturas, as bases religiosas são carregadas pelo classismo, pelo racismo, pelas opressões/violências e pelas desigualdades entre os gêneros. É imperativo dizer que a esfera religiosa não está isenta dos incômodos patriarcais que acometem a sociedade como um todo, destarte tais instituições padecem dos mesmos achaques.

No que diz respeito à segunda questão, julga-se que as categorias gênero e masculinidade guardam posições genéricas, isto é, não possuem definição objetiva relacionada à mulher ou qualquer outro gênero, posto que as categorias acima não estejam circunscritas, respectivamente, à mulher ou ao homem. No mais, são construtos formados e assentados na esfera sociocultural. Tanto é verdade que as mulheres negras questionam as posições defendidas pelos feminismos europeus e estadunidenses, uma vez que as negras não se sentiam contempladas nas discussões feitas por estes. As intelectuais negras brasileiras como, Bairros (1995), Carneiro (2003) e Gonzalez (2014), dentre outras, cobram as especificidades no trato dos assuntos relativos à mulher. Portanto, tal como Pateman (1993) e Saffioti (2004) defendem a ideia de que o patriarcado é a única categoria que explicita o tratamento desigual, a dominação, a sujeição e a exploração econômica relativas às mulheres. 
[...] representaria, na minha maneira de entender, a perda, pela teoria política feminista, do único conceito que se refere especificamente à sujeição da mulher, e que singulariza a forma de direito político que todos os homens exercem pelo fato de serem homens. Se o problema não for nomeado, o patriarcado poderá muito bem ser habilmente jogado na obscuridade, por debaixo das categorias convencionais da análise política [...] Grande parte da confusão surge porque 'patriarcado' ainda está por ser desvencilhado das interpretações patriarcais de seu significado. (PATEMAN, 1993 apud SAFFIOTI, 2004, p. 55).

Com isso, ressalta-se a importância de localizar as bases que estruturam as ações da masculinidade hegemônica que tanto impactam a vida de pessoas que optam por viver fora dos padrões da heteronormatividade ${ }^{8}$. Em contrapartida, ainda que a maioria das mulheres esteja sob as ações do patriarcado, é possível que existam experiências que fujam a essa universalização. No Brasil, a Irmandade da Boa Morte e a atuação das mulheres nos candomblés são dois exemplos que podem ilustrar o apresentado.

As justificativas para entender a Irmandade da Boa Morte como um dos primeiros movimentos feministas no Brasil que burlam, de algum modo, o sistema patriarcal, residem nos seguintes fatos, aqui, apresentados por nós: As integrantes eram apenas mulheres negras africanas libertas e/ou alforriadas, supostamente das etnias Jeje e Nagô; O grupo empunha uma luta para garantir a sobrevivência de ritos africanos importantíssimos para preservação da ancestralidade, no tocante à morte e sua ritualística, assim como o culto aos orixás;

A Irmandade da Boa Morte tem como base o sentido de dupla pertença, o qual permite a circulação de suas integrantes tanto no candomblé quanto no catolicismo. Salvo engano, foi o primeiro grupo a levantar a bandeira contra o heterossexismo religioso. Na medida em que ela não possuía Estatuto ou Compromisso aprovado pela Cúria da Igreja Católica que a legitimasse, enquanto irmandade, o que justificaria a historiografia oficial considerá-la como uma devoção.

Já no candomblé, as mulheres sempre ocuparam lugar de proeminência sacerdotal, tanto do ponto de vista político quanto religioso; espaço de acolhimento e de preservação de bens materiais e imateriais africanos. A historiografia e registros antropológicos apontam para a existência de outras instituições negras, como a Sociedades secretas Geledé,

${ }^{8} \mathrm{O}$ termo heteronormatividade é utilizada neste texto a partir do pensamento Richard Miskolci (2009), para quem o conceito refere-se a um conjunto de prescrições que fundamenta processos sociais de regulação e controle, até mesmo aqueles que não se relacionam com pessoas do sexo oposto. 
Sociedade Egungum e Egboni ${ }^{9}$ que lutaram tanto pela manutenção dos saberes religiosos quanto por políticas para melhores condições de vida. Apesar de existirem esses espaços de protagonismo das mulheres negras, as instituições nas quais atuavam e atuam continuam sendo patriarcais e dominadas por concepções heterossexistas, o que desnuda a égide da masculinidade como forma de dominação.

\section{MASCULINIDADE RELIGIOSA, VIOLÊNCIA EM ESPAÇO SAGRADO}

Feitas as devidas ponderações acerca das categorias analíticas utilizadas neste texto, passamos a discorrer sobre um assassinato de uma lalorixá, ocorrido na década de 90, na cidade de Maracanaú, região metropolitana de Fortaleza, Ceará. No referido caso, a opressão/violência aparece em intersecção com outras categorias, como masculinidade, sexismo e dominação. Os conceitos se retroalimentam na concretude dos fatos, associados à negação da população negra e indígena, sistematicamente invisibilizadas nos registros oficiais do Estado, cuja formação originária é atribuída quantitativamente aos europeus, especialmente aos holandeses e franceses, e somente depois às etnias indígenas e negras.

No Estado do Ceará o discurso da negação é atenuado pela narrativa de que o estado ostenta o título de ter sido o primeiro a efetivar a liberdade dos negros escravizados. Tanto é verdade que a sede da Universidade da Integração Internacional da Lusofonia Afro-Brasileira (UNILAB) foi edificada em Redenção, primeira cidade do país a libertar os cativos. Importa realçar que tais comportamentos corroboram o menosprezo pela cultura e as múltiplas manifestações oriundas do continente africano. Por vezes, a negação de uma população resulta em uma violência, e como tal, conclama outras práticas de violência dentro de uma dada estrutura. Assim, em uma sociedade racista o patriarcado, aliado ao sexismo, pode ser o terreno ideal para o florescimento de um tipo de masculinidade revestida pelo sagrado.

\section{NARRANDO OS FATOS}

Mãe Obassi de Obá ou Mãe Franci, nasceu Francisca Maria da Justa Teixeira, no dia 10 de setembro de 1943, na cidade de Fortaleza/ CE; filha biológica de Aurélio Bentes Teixeira e Maria do Carmo Justa Teixeira. Quando criança, foi batizada na religião católica, mas ainda jovem começou a frequentar um terreiro de Umbanda localizado no bairro da Serrinha, do conhecido pai-de-santo José Maria, onde foi feita Mãe de Santo, guiada pelas entidades Nobre Guerreira e a Pombagira Sete Encruzilhadas.

\footnotetext{
${ }^{9}$ Sobre as sociedades secretas que existiam na Barroquinha -Salvador, no século XIX ver Renato da Silveira (2006).
} 
Após concluir o curso de contabilidade, por razões pessoais, na década de 60, viajou para o Rio de Janeiro, estabelecendo moradia. Lá deu continuidade a sua vida religiosa na Umbanda. Todavia, a partir de novas relações conheceu o candomblé, nomeadamente, o llê Axé Aganju, de nação Angola, localizado em Duque de Caxias, conduzido pelo Pai-de-santo Agil Efon, ou Babá Obiladê, passando a frequentar sistematicamente a referida casa e mantendo estreita amizade com sacerdote dentro e fora do axé. Não obstante, ela daria novos passos em direção a sua ancestralidade.

Segundo Ogã Luiz Leno, Babá Agil era muito respeitado na Baixada Fluminense, por isso era frequentador de várias casas de candomblé do Rio de Janeiro. Em uma dessas casas, conheceu o famoso Babalorixá Valdomiro da Costa Pinto - Pai Valdomiro de Xangô, ou Pai Baiano -, de quem se tornara muito amigo e, mais tarde, filho-de-santo, já que ele tomaria uma de suas obrigações de anos de iniciação com Pai Baiano.

Quanto à Mãe Franci, acredita-se que a essa altura ela frequentava outras casas de nações diferentes no universo do candomblé, o que despertou seu interesse pela iniciação na matriz africana, já que ostentava o título de Mãe-de-santo na linha umbandista. Todavia, no llê Axé Aganju, do Pai Agil, não se cultuava o referido orixá para qual deveria iniciar Mãe Franci, razão pela qual Pai Agil que já havia tomado suas obrigações no terreiro do Babalorixá Valdomiro, o procura a fim de iniciar Mãe Obassi nos mistérios dos orixás, como relata Ogã Leno:

No Candomblé, Mãe Obassi foi iniciada em 13 de abril de 1971 no Terreiro llê Axé Aganzú do falecido Babalorixá Obiladê - Agil Efon, pelas mãos do Babalorixá Valdomiro da Costa Pinto (falecido) situado na Baixada Fluminense, Rio de Janeiro/RJ. (Ogã Luiz Leno Faria. Entrevista I. (abr.2020). Entrevistador: Joanice Conceição. Fortaleza, 2021. 1 arquivo. Questionário. A entrevista na integra encontra-se digitada nos arquivos pessoais da entrevistadora

Cumpre ressaltar que Mãe Franci foi iniciada, tendo a orixá Obá como regente de seu Ori -cabeça, pelo já citado Valdomiro de Xangô, este por sua vez teve sua iniciação realizada por Cristóvão Lopes Santos de Ogunjá, no Terreiro llê Axé Ogum Anauegi, no bairro Albarana em Salvador, Bahia, terreiro descendente do Alaketu, uma das principais casas do candomblé da cidade de Salvador. Portanto, Mãe Franci foi iniciada "na raiz da Bahia", gozando assim do prestígio religioso dos afamados candomblés do Brasil, o que seria no futuro um dos motivos para rivalidade.

A partir da iniciação no candomblé, Mãe Franci mantém relações estreitas tanto no terreiro do Babá Agil quanto no Pai Valdomiro. Ainda no Rio de Janeiro, teve seu primeiro filho biológico, Marcos da Justa Tei- 
xeira - o Marcos de Oxossi. Durante o tempo em que residiu na região Sudeste, retornou à Fortaleza muitas vezes e, em algumas dessas viagens, trouxe em sua companhia Babá Agil, ekedis e pessoas graduadas no santo. Na oportunidade, atendia clientes, fazia limpezas, ebós (oferendas) e dava obrigação de bori (oferenda dedicada à cabeça) para as pessoas que futuramente viriam ser seus filhos-de-santo, espalhando assim sua fama em todo Estado.

Nos anos 80, Mãe Obassi resolve voltar em definitivo para Fortaleza devido a perda do seu pai e amigo Agil de Efon e ao grave estado de saúde sua mãe biológica. Em 1983, ela já possuía um número significativo de filhos-de-santo, cerca de vinte, no entanto, outras pessoas frequentavam a casa assiduamente. Em 1988, ela compra um terreno em Maracanaú, região metropolitana de Fortaleza, para construção do seu terreiro. Segundo Bandeira (2009), na época ela contou com a ajuda de diversos filhos-de-santo que realizavam bingos e leilões para angariar fundos para construir em mutirão de fim de semana o axé. Ademais, contou também principalmente com a ajuda da Ebomi Valdenízia de lemanjá, que nas palavras do Ogã Luiz Leno foi fundamental para que em dois anos o terreiro estivesse pronto.

Em 30 de junho de 1990 Mãe Obassi, juntamente com seu Babalorixá Valdomiro de Xangô -o Pai Baiano, que se fazia acompanhar pela Ekedi Cremilda, Yara de Nanã e Nilda de lemanjá, fundam o llê Axé Oloioba, localizado na rua da Conceição, número 20, bairro Planalto Cidade Nova, no munícipio de Maracanaú, Ceará. Na oportunidade, o Pai Baiano conduziu a saída do primeiro barco, constituído por "Toinha de Ogum, Kaká de Oxossi, Valdenízia de lemanjá, Maira de Ewá e Marcos de Oxossi, as duas últimas pessoas, filhas biológicas de Mãe Obassi" (BANDEIRA, 2009, p. 86).

A partir daí começava um novo ciclo, isto é, o Pai Valdomiro voltaria ao Oloioba em diferentes festividades, junto com seus filhos-de-santo. Ao longo dos anos a casa passou a ser procurada por pessoas do Ceará, do Acre, Brasília, Roraima e até do Rio de Janeiro. Vale salientar que com o retorno de Mãe Obassi para Fortaleza as religiões de matrizes africanas praticadas até então ganhariam novos contornos, jamais seriam as mesmas. Veja a fala abaixo de um filho-de-santo e Ogã da referida casa:

Desde sua chegada em Fortaleza Mãe Obassi torna-se um esteio de práticas ancestrais na realidade do candomblé do Ceará [sic]. Podemos citar como contribuições para o candomblé do Ceará a utilização do ritual de Xirê, o jogo de Búzios por Odun, antes era Bantu (Jogo chamado de TELAMEZÔ); o ritual de iniciação com apenas três saídas no salão, antes eram cinco; o ritual do Amalá da quarta-feira em reverencia a Xangô [sic]. Antes dela quarta-feira 
era dedicada a Caboclo de Nação; o ritual de Sassayn; o ritual de Ipadê; o ritual de Itá e suas ramificações. Mas devemos reforçar o calendário litúrgico feito por ela para o Estado do Ceará; antes dela as Casas faziam festas esporádicas ou de saída de iniciados ou de obrigações grandes. A única casa que tinha rituais na sua nação era o llê Igbá Possum. Mãe Obassi [sic] traz a festa de Ogun no Sábado de Aleluia com reconstrução da festa de seu Pai de Santo Valdomiro de Xangô, onde Ogun distribui os Pães de Santo Antônio[sic]; a festa de Oxossi no Corpus Christis; a festa do Olubajé no segundo sábado de agosto; a festa das Yagbas no segundo sábado de dezembro ${ }^{10}$. (Ogã Luiz Leno Faria. Entrevista I. (abr.2020). Entrevistador: Joanice Conceição. Fortaleza, 2021. 1 arquivo. Questionário. A entrevista na integra encontra-se digitada nos arquivos pessoais da entrevistadora

Como mostra a citação em destaque, muitas mudanças foram realizadas e novos aspectos rituais foram acrescentados às religiões de matrizes africanas no estado do Ceará. Normalmente, o novo costuma atrair olhares diversos tanto positivos quanto negativos e, com o llé Axê Oloioba, não foi diferente. A lalorixá possuía prestígio religioso e político, já que vários candidatos a consultavam sobre previsões eleitorais e/ou para realizar trabalhos (ebós). Além das transformações promovidas, ela ainda alteraria as relações com a família-de-santo, uma vez que seu terreiro era muito visitado pelos parentes de santo do Rio de Janeiro e Bahia, fato incomum. Normalmente, as festas do Oloioba tinham início às 21 horas com término às 6 da manhã do dia seguinte, com buffet e garçons, também inovações feitas por ela.

Por todo exposto, suas festas eram muito concorridas desde pessoas do Movimento Negro, lideranças políticas locais e de outros estados (Rio de Janeiro, Acre, Roraima e, Brasília), assim como lideranças religiosas do próprio estado, que buscavam conhecimentos no tocante à organiza-

\footnotetext{
${ }^{10}$ As pessoas entrevistadas para fornecer dados empíricos para embasar esse artigo foram contactadas por telefone, o questionário enviado por e-mail, respondido e reenviado pelo mesmo meio. A escolha por este procedimento se justifica tendo em vista o contexto de Pandemia, face ao Coronavírus ou COVID-19, doença infecciosa causada por um vírus recém-descoberto, na China, no ano de 2019. Saliento ainda, que nas narrativas apresentadas neste texto foram feitas pequenas supressões para adequar e realçar a importância do conteúdo. Entretanto, as partes suprimidas não prejudicam a compreensão daquilo que expressaram os/as entrevistados/as. Foram feitas 5 entrevistas, destas, 3 eram mulheres e 2 homens. Considerando que as informações das falas e nos questionários se repetiam, optei por aplicar a técnica de "bola de neve", isto é, as informações tornaram-se saturadas, por isso utilizei apenas a interlocuções de duas pessoas. Ressalto ainda que para algumas entrevistas foi necessário fazer contato novamente por telefone, a fim de iluminar respostas dadas ao questionário.
} 
ção, às danças rituais, às cantigas e aos toques para invocar os orixás.

Mãe Obassi estava no auge da fama, dada a competência religiosa, visibilidade política e pela inserção de tantas novidades no cenário religioso do estado do Ceará. À medida que muitas lideranças viam nela a oportunidade de aprendizado na ritualística da nação Ketu. Por outro lado, existiam pessoas, especialmente lideranças religiosas, que falavam que as mudanças promovidas por Mãe Obassi eram invencionices, desqualificavam-na com palavras pejorativas: "mentirosa", "marmoteira". Com o crescimento do número de filhos, fama e reconhecimento criou-se uma tensão no campo religioso das matrizes afro-cearenses, gerando rivalidade, descontentamento, disputa pela liderança religiosa e práticas sexistas. Tais sentimentos desencadeariam uma série de conflitos que colocaria em relevo a disputa, as hierarquias, as disjunções provocadas pelas desigualdades entre os gêneros, culminando assim, no assassinato/feminicídio de Mãe Obassi.

Importa ressaltar que na pesquisa exploratória encontramos relatos de que havia picuinhas entre Mãe Obassi e o Babalorixá Luiz de Xangô. Ele a difamava, dizia que iria fazer feitiço para matá-la e outros impropérios. Além das ofensas dirigidas a referida lalorixá, ele também era conhecido no meio religioso por ameaçar as pessoas de morte, por meio da prática de feitiço; ele se impunha através das ameaças. No dia 22 de dezembro de 1996, houve um episódio que mancharia a história do candomblé do Ceará. No mês de dezembro fazia parte do ciclo de festejos, a realização das festas dedicadas às labás (orixás femininos); antes de começar, Luiz de Xangô, mesmo não sendo convidado, compareceu ao Oloioba fazendo arruaça. Neste momento, alguns filhos-de-santo da casa intervieram solicitando que ele se retirasse, o que não ocorreu. Diante da negativa, a própria Mãe Obassi interveio, de modo que ele se retirou. Entretanto, ante da vergonha perante aos presentes, disse em "alto e bom som" que o fato não ficaria sem resposta. A festa teve início e todos ocupavam o barracão, como mostra a narrativa do então Luiz Leno, Ogã, filho do llê Axé Oloioba e testemunha ocular do episódio:

Enquanto Mãe Obassi dançava incorporada o Orixá Obá, aliás quem dançava era Obá, um homem portando um capacete de motoqueiro, para não ser reconhecido, entrou no barracão, sacou um revólver e, pelas costas, disparou um tiro na cabeça da Mãe Obassi. Na verdade, ele atirou em Obá, que sentiu o impacto, mas continuou dançando, depois disparou mais um tiro na cabeça novamente e, nossa Mãe Obassi/Oba continuou dançando até cair no chão. Neste momento, todos os orixás incorporaram em seus filhos-de-santo. Ninguém pode fazer nada, pois o homem parecia 
que era um louco, apontou a arma em direção de todos os presentes. Parecia que havia uma grande tragédia naquele momento, todos os orixás estavam incorporados em seus filhos [sic]. Foi um verdadeiro terror, tudo aconteceu tão rápido. (BANDEIRA, 2009, p.93).

Outra narrativa revela o impacto da morte da lalorixá:

Recebi a notícia no dia seguinte ao triste acontecimento, logo de manhã bem cedo. Lembro de sentir um tremor incontrolável por todo o corpo, e confesso que, mesmo hoje, falar deste assunto me provoca uma sensação de deslocamento momentâneo neste mundo: ora, uma lalorixá, Mãe e mulher, assassinada em pleno ritual sagrado de nossa religião... Atrevo-me a supor que as gerações atuais da nossa religião jamais sentirão este fato do mesmo modo que as outras mulheres de candomblé contemporâneas o sentiram. Mais tarde, soubera, por meio de pessoas da religião, que o famigerado Babalorixá (se é que ele merece este título, tamanha a ignomínia de seu ato) havia pontificado o "fim do candomblé de mãe-de-santo no Ceará", pois ele próprio se encarregaria de dar cabo da vida daquelas que estivessem em atividade (grifo nosso). (Iyá Valéria de Logun Edé. Entrevista II. (abr, 2020). Entrevistador: Joanice Conceição. Fortaleza, 2021. 1 l arquivo. Questionário. A entrevista na integra encontra-se digitada nos arquivos pessoais da entrevistadora

As narrativas em destaque deixam entrever a violência do episódio; o ódio era tão grande que o agressor não se importou que a lalorixá estivesse incorporada no Orixá, que o corpo daquela mulher estivesse a serviço do sagrado. No primeiro depoimento, é destacado que, mesmo após o primeiro tiro, Mãe Obassi/Obá não caíra, evidenciando as características da Orixá guerreira e destemida que é Obá. Já no segundo, a lyá Valéria de Logum Edé mostra o caráter sexista que permeou o assassinato ou feminicídio. Com efeito, classifico o ato como feminicídio, já que no trecho em negrito o mandante do crime deixa evidente que a morte ocorreu por se tratar de uma mulher que estava na liderança religiosa do estado.

Após serem identificados, Luiz Dias ou Pai Luiz de Xangô, como mandante do crime, e Claudeci Vieira Uxôa, como executor, ambos foram julgados, condenados e presos pelo crime; Luiz de Xangô, segundo diversos relatos, morreu com uma doença misteriosa alguns anos depois e Claudeci morreu no presídio. 
Das matérias ${ }^{11}$ jornalísticas da época, dissertação de mestrado, relatos e testemunhos recolhidos que narram os momentos derradeiros de Francisca Maria Justa Teixeira, Mãe Franci ou Mãe Obassi, quase todas as fontes trazem à tona questões relativas à expansão do candomblé e a disputa pela liderança religiosa, com exceção de lyá Valéria que falou prontamente sobre feminicídio. Ainda que Mãe Obassi e Luiz de Xangô possuíssem prestígios e reconhecimento social e religioso no estado do Ceará, a maior parte das informações afirma que o assassinato da lalorixá Obassi estava associado a disputa por filhos e clientes, sem considerar outras questões que perpassam o acontecimento. Entendemos ser preciso olhar para o caso de maneira interseccional, jogando luz para as questões relacionadas ao patriarcado, disputa por espaço, mas, sobretudo, para o exercício da masculinidade no interior dos ambientes religiosos, posto que o processo de produção de saber além das categorias já citadas, envolvem relações de poder, sexo e raça.

Outro ponto que precisa ser observado é que a inserção da mulher nas instituições religiosas, especialmente nas ocidentais, sempre foi ponto de tensão. Dessa afirmação, podemos intuir que o conflito causado pela presença da Mãe Obassi parece residir no fato dela iniciar uma ocupação de um espaço que sempre esteve atrelado a égide masculina. Chamamos a atenção para o fato de, apesar do assassinato/feminicídio ter ocorrido no contexto das religiões de matrizes africanas e, que em muitas situações se opõem à cosmovisão ocidental, mesmo assim, não se pode furtar a ideia de que elas acabam por sofrer suas influências e delas apreendem valores positivos quanto negativos, como é o caso das opressões de gêneros infligidas às mulheres e outros grupos que fogem aos padrões binários.

Em algumas circunstâncias dentro das religiões de matrizes africanas, em termos de genitália, tanto a presença de homens quanto de muIheres é razão para interdito, neste sentido a presença de Mãe Obassi no cenário do Ceará parecia dessacralizar a essência daquilo que se praticava, pondo em relevo a ambivalência em relação à figura feminina. Dito de outro modo, a presença da mulher macularia o imaginário do "candomblé de homem" do Ceará. Ogã Luiz Leno ressalta que, quando do retorno de Mãe Obassi, em Fortaleza juntamente com a região metropolitana não havia mais que doze casas de Candomblé e dessas, apenas quatro eram

\footnotetext{
${ }^{11}$ Homicídio de Mãe-de-santo é gravado. Reportagem da Folha de São Paulo, Caderno Cotidiano, em 26 de dezembro de 1996. Disponível em: https://www1.folha.uol.com. br/fsp/1996/12/26/cotidiano/19.html Acesso em: abr. 2020.

Criminalística identifica assassino de Mãe-de-santo. Reportagem da Folha de Londrina, Caderno Folha Cidade. Em 20 de fevereiro de 1997. Disponível em: https://www. folhadelondrina.com.br/cidades/criminalistica-identifica-assassino-de-mae-de-santo-da-redacao-10318.html. Acesso em: abr. 2020.
} 
lideradas por mulheres. Estas lideranças eram Mãe Obassi, Mãe Ilza, Mãe Valeria, Mãe Jussara.

A presença da referida lalorixá afetou a imagem que se tinha das religiões africanas no cenário cearense, à medida que ela imprimiu elementos inexistentes na liturgia do candomblé do estado, provocando deslocamentos de percepção da figura da mulher, já que se tornara líder. Não atuava apenas no terreiro, mas influenciava na vida política seja junto a pessoas nas esferas do governo estadual e municipal, bem como nos dos movimentos sociais em favor das religiões de matrizes africanas quanto das questões raciais. Como uma filha de Obá, cuja simbologia está nas águas revoltas e pororocas, ela foi a mulher que redefiniu o candomblé cearense, colocando em desuso as identidades masculinas tidas como fixas e absolutas. A partir dela, o espelho refletia a imagem de uma mulher negra, mãe solteira e líder religiosa legitimada por diferentes setores sociais, corroborando a ideia de que as identidades são móveis e flutuantes (CONCEIÇÃO, 2017). Segundo Kilomba (2019), o juízo de sujeito reúne o caráter político, social e individual, fulcrais para a construção da subjetividade que, por conseguinte, auxiliam na construção do imaginário positivo acerca de uma pessoa, essas três características podiam ser encontradas em Mãe Obassi.

Voltando a olhar para a história de Mãe Obassi, relacionando-a com os símbolos culturais, percebe-se como tais símbolos auxiliam na formação de uma mentalidade masculinizada, androcêntrica, em oposição à figura feminina, associada à maternagem, à esfera doméstica, à fragilidade e à incapacidade para a área administrativa. Muito embora essa visão divirja da centralidade ocupada pela mulher em algumas sociedades africanas. A utilização dos símbolos nos espaços religiosos, em grande medida, acaba por naturalizar as desigualdades entre os gêneros e, consequentemente, ainda que de forma velada, legitima as violências. Talvez, essa mentalidade se justifique a partir da negação da proeminência alcançada por Mãe Obassi. Os símbolos encerram uma significância que cooperaram para segregação espacial e por decorrência apagam materialmente o feminino em ascensão nas religiões.

A masculinidade nunca pode ser lida da mesma maneira, antes há que se considerar o relevo social, a raça, a classe, a religião e, sobretudo, o aspecto dos gêneros. Se, por um lado, a Mãe Obassi possuía o status religioso, frequentemente ressaltado por grande parte dos adeptos de candomblé, por outro, o fato dela ser mulher a colocava em um lugar menor; no que tange a posição das mulheres nas sociedades tidas como modernas. Os avanços observados não foram suficientes para lhe assegurarem a manutenção no posto de destaque que outrora sempre esteve reservado aos homens, ao contrário, a representação da tradição patriarcal e o exer- 
cício da masculinidade na economia e nos bens simbólicos lhe reservaram um lugar da violência, da misoginia. Foi no eurocentrismo que o algoz de Mãe Obassi encontrou suas bases para o exercício da dominação:

A divisão sexual está inscrita, por um lado, na divisão das atividades positivas a que nós associamos a ideia de trabalho, assim como mais amplamente, no trabalho de manutenção do capital social e do capital simbólico, que atribui aos homens o monopólios de todas as atividades oficiais, públicas, de representação, e em particular de todas as trocas de honra, das trocas de palavras (encontros quotidianos e sobretudo, nas assembleias), trocas de dons, trocas de mulheres, trocas de desafios de mortes [sic], as das mulheres, que está na economia reduz ao estado de objetos de troca (mesmo quando, em determinadas condições, elas podem contribuir, pelo menos por procuração, para orientar e organizar as trocas, sobretudo matrimoniais). (BOURDIEU, 2010, p. 60).

As ideias contidas nas palavras de Bourdieu encontram eco nas práticas da segregação religiosa vivida pelas mulheres; homem religioso, discriminando, violentado e assassinando uma mulher. Seria por assim dizer, que a discriminação promovida pela masculinidade religiosa à feminilidade igualmente religiosa, na escala de valoração dos gêneros mostra-se assimétrica e desigual. Partindo dessa perspectiva, podemos dizer que, no âmbito dos candomblés e demais religiões de bases africanas, as pessoas negras e sua cultura são constituídas no espelho de um aparelho ideológico, calcado pela masculinidade hegemônica. Contudo, as ideias de Bourdieu (2010) se assemelham com as desigualdades de gênero no Ceará, no que se refere ao exercício do sacerdócio feminino. "[...] só hoje eu consigo mais ou menos intuir: o ser Mãe de Santo numa terra de homens, marcada pelo desequilíbrio de poder". (Iyá Valéria de Logun Edé. Entrevista II. (abr, 2020). Entrevistador: Joanice Conceição. Fortaleza, 2021. 1 l arquivo. Questionário. A entrevista na integra encontra-se digitada nos arquivos pessoais da entrevistadora

Na época da atuação da Mãe Obassi, lyá Valéria era uma das 4 lideranças femininas na cidade de Fortaleza que reconhece o papel de proeminência religiosa em um terreno marcado pela égide masculina. Por conseguinte, a dominação masculina varia conforme o tecido social, por outro lado, ela se mantém inalterada no tocante à opressão. No caso em questão, a lalorixá não teve apenas o seu corpo vilipendiado, mas todos os aspectos simbólicos enquanto representante de todas as demais sacerdotisas. Por vezes, a masculinidade não muda seu caráter violento, tão somente veste-se com uma nova roupagem para impor à dominada o desejo de quem domina (CONCEIÇÃO, 2013). 
Grosso modo, as religiões de matrizes africanas, com especial atenção para as cearenses, constroem suas bases no reflexo de um apareIho ideológico, cuja sustentação está no patriarcado, que por sua vez permite o avivamento de uma masculinidade religiosa revestida pelo sagrado a fim de exercer o poder, ainda que essa masculinidade esteja fora dos parâmetros dominantes. Inicialmente, chamamos atenção para a diferença da masculinidade religiosa e, neste ponto, ela se torna útil ao sistema quer para manter as mulheres subjugadas a autoafirmação do domínio masculino. Particularmente, no caso do Ceará, o algoz julgou que contaria com o "consentimento" do aparelho da masculinidade hegemônica, tendo em vista que na maior parte das ocorrências de violência física, psicológica e mesmo assassinatos, o agressor tende ficar impune. $\mathrm{O}$ assassinato/feminicídio em questão pode ter sido utilizado ora para decretar o fim da trajetória de uma mulher de sucesso, ora para enviar um recado para as demais lideranças de femininas.

O que mais suscita reflexão sobre a morte de minha amiga Mãe Obassi são as circunstâncias do crime, bem como seus agentes: ambos homens: o mandante foi, justamente, um outro Babalorixá cujo nome eu me recuso a pronunciar, ou mesmo escrever, enquanto mulher, lalorixá e amiga de Obassi. Deixo esta tarefa por conta dos altos do crime e dos jornais que reportaram esta terrível notícia; o executor foi outro homem que atravessou o barracão portando um capacete de motoqueiro, até chegar ao Orixá incorporado de Mãe Obassi. ${ }^{12}$. (Iyá Valéria de Logun Edé. Entrevista II. (abr, 2020). Entrevistador: Joanice Conceição. Fortaleza, 2021. 1 l arquivo. Questionário. A entrevista na integra encontra-se digitada nos arquivos pessoais da entrevistadora

O relato acima corrobora as definições sobre as características da masculinidade. Iyá Valéria, como mulher, chama atenção para a altivez e poder de liderança de Mãe Obassi. Além disso, expõe uma das motivações para o assassinato/feminicídio, na medida em que ele se arvorava dizer que tinha posto fim no candomblé de mãe-de-santo no Ceará. Reforça ainda que o problema não estava unicamente na figura de Mãe Obassi, mas residia no fato do mandante do crime não aceitar que o candomblé no Ceará estivesse sendo protagonizado por uma mulher, negra e mãe solteira. Com efeito, poder-se-ia dizer que a ação do Babalorixá Luiz de Xangô foi, antes de mais nada, uma questão com o feminino, antes mesmo da sede pelo poder, como bem formulou o filósofo francês:

\footnotetext{
${ }^{12}$ Entrevista concedida Por lyá Valéria de Logum Edé. Entrevistadora Drá Joanice Conceição.Fortaleza, 2020. A íntegra desta entrevista encontra-se nos arquivos pessoais da autora.
} 
O poder deve ser analisado como algo que circula, ou melhor, como algo que só funciona em cadeia. Nunca está localizado aqui ou ali, nunca está nas mãos de alguns, nunca é apropriado como riqueza ou bem. O poder funciona e se exerce em rede. Nas suas malhas os indivíduos não só circulam, mas estão sempre em posição de exercer este poder e de sofrer sua ação; nunca são o alvo inerte ou consentido do poder são sempre centros de transmissão. (sic) O poder não se aplica aos indivíduos, passa por eles. (FOUCAULT, 1979, p. 183).

Foucault alerta que o exercício do poder é circular, com o funcionamento em rede e que todas as pessoas sempre podem ocupar o lugar, contudo, não ressaltou o fato de que as mulheres quase sempre são interditadas em determinados espaços, especialmente os públicos. Do ponto de vista simbólico, o poder exercido na diferença entre os gêneros foi muito bem apreendido pelas organizações religiosas do Ceará.

Conquanto, materialmente, os tiros que atingiram Obá/Mãe Obassi a mataram. Luiz de Xangô, portanto, acreditava ter posto fim a uma ameaça que o rondava. Espalhou que se outra mulher tentasse ocupar a liderança religiosa, teria o mesmo fim. Na mentalidade do mandante do crime, o assassinato/feminicídio da lalorixá se tornaria uma espécie de "aviso", isto é, o assassinato/feminicídio serviria como fator amedrontador para que outras mulheres não ousassem fazer o mesmo. Foi por meio da morte simbólica do corpo da lalorixá que o algoz encontrou meios para dominá-la, já que "O corpo é o primeiro e o mais natural instrumento do homem, ele é modelado conforme os habitus culturais. Ele pode ser dominado, mas ele também pode ser resistência (LE BRETON, 2006, p. 39). Isso nos leva a acreditar ser o patriarcado o fornecedor das bases para a masculinidade religiosa, que por vezes se intersecciona com as violências materiais e subjetivas resultando em um feminicídio nunca visto na história das religiões de matrizes africanas do Ceará, quiçá Brasil. Iyá Valéria é categórica ao falar sobre os verdadeiros motivos para tamanha agressão.

[...] não preciso dizer que, além da dor da perda e da vergonha de ter nosso sagrado maculado por um assassinato brutal, padeci de medo por minha própria vida. Passei a frequentar outros candomblés escoltada por filhos-de-santo, que temiam que a história se repetisse, tendo, agora, como vítima sua mãe. Ambos, mandante e executor, foram presos e, tempos depois, faleceram de causas naturais. Mas, mesmo agora, pergunto-me: qual a verdadeira motivação deste crime, cujo sangue proveniente jamais sairá do aiê do candomblé no Ceará? Inveja? Despeito? Sim! Afinal, Obassi era majestosa e sua memória vai muito além da maneira vil que foi 
assassinada. No entanto, é preciso dar nome a cada boi que passa na estrada dessa vida: foi um crime movido pelo macho humano pensante e profundamente tomado pela misoginia! Sim! Foi ódio à mulher forte e farta de dádivas que era minha amiga Mãe Obassi. (Iyá Valéria de Logun Edé. Entrevista II. (abr, 2020). Entrevistador: Joanice Conceição. Fortaleza, 2021. 1 l arquivo. Questionário. A entrevista na integra encontra-se digitada nos arquivos pessoais da entrevistadora

As palavras de lyá Valéria são carregadas de muita consciência de que o assassinato/feminicídio de sua amiga estava relacionado ao fato dela ser mulher, logo, poderíamos dizer que é uma questão de feminicídio, "foi um crime movido pelo macho humano pensante e profundamente tomado pela misoginia!" A masculinidade religiosa é também aquela que passa pelo poder, pela força e pelo prover, tais características são encontradas em Deus que, na visão ocidental, é homem e está acima de tudo e de todas. Nesta perspectiva, pode-se intuir que o feminicídio de Mãe Obassi faz parte de um conjunto de elementos que atesta não apenas a honra do macho, já que a afirmação da masculinidade está na demonstração da capacidade que o homem tem de dominar a mulher. Dito de outra forma, a masculinidade é construída no espelho da feminilidade dominada.

Os efeitos da masculinidade religiosa não atingem apenas as muIheres, mas aqueles que seus dominadores julgam frágeis e domináveis. Visto que ela é um dos produtos da ordem patriarcal, faz parte de um esquema muito maior que perpassa instituições, como família, escola e religião, dentre outras (SAFFIOTI, 2004).

Diferente das matérias e relatos colhidos sobre o episódio que envolveu o fim material de Mãe Obassi, como supramencionado, apenas a Iyá Valéria faz menção a sua condição de mulher. Nas demais, o episódio é tratado como um assassinato, com uma dose de sutileza para conduzir os fatos apenas pela disputa por clientes, portanto o fato dela ser mulher foi naturalizado. No entanto, nas entrelinhas é possível entrever as características de um feminicídio, à medida que a morte foi violenta, por motivo torpe e sem chance de defesa. Acrescenta-se que feminicídio é um dos assuntos mais comentados na atualidade; não é coincidência que o Brasil esteja entre os países que mais cometem feminicídio. Neste sentido, o feminicídio é uma das roupagens de que se reveste o velho patriarcado. Ademais, ele - o patriarcado - expõe a necropolítica perpetrada contra as mulheres. Conquanto, pode-se compreender que o assassinato/feminicídio de Mãe Obassi pode levantar a hipótese de que sempre existiu um 
necrofeminino ${ }^{13}$, parafraseando Mbembe (2018).

Outra questão que não é suscitada nas matérias jornalísticas e nem nas narrativas colhidas é a razão de ela ser negra. No Brasil, a morte de pessoas negras é banalizada e naturalizada até mesmo pelas instituições que deveriam protegê-las. Ainda que para produção desse artigo fossem ouvidos filhos-de-santo, Ogã e amigas de Mãe Obassi, nenhuma delas trouxe espontaneamente essa informação. Mais uma vez, a negação da população negra no Ceará é escamoteada. Ao relacionar o evento ocorrido com a questão da raça, pode-se entrever que, talvez, sendo o Babalorixá Luiz de Xangô um homem branco, não podia admitir que uma mulher negra e mãe solteira se sobressaísse mais que ele. Mesmo que a condição de homossexual colocasse o Babalorixá em inferioridade quando observada a escala de valoração dos gêneros, uma vez que as masculinidades dos homossexuais são frequentemente classificadas no interior do padrão de subalternidade.

\section{CONSIDERAÇÕES FINAIS}

Ao longo do texto buscamos demonstrar como a religião corrobora para a manutenção das desigualdades entre os gêneros. Lançamos algumas luzes para o caso do feminicídio de uma lalorixá, que por circunstancias explicitadas por nós, tornou-se uma liderança religiosa, a ponto de colocar na berlinda a hegemonia masculina nas religiões de matrizes africanas no Ceará. Os efeitos do patriarcado deslindaram na masculinidade religiosa, no sexismo e na violência, criando assim, um espaço ideal para a contestação da alternância de poder. Os próprios símbolos religiosos subordinam a atuação das mulheres nos espaços religiosos.

Buscamos justificar o uso de alguns conceitos, especialmente acerca do patriarcado, um dos principais embasadores da argumentação, especialmente na análise do caso de Mãe Obassi. A partir da reflexão sobre as categorias, pode-se perceber que, embora o espaço religioso por meio de seus discursos procure homogeneizar as pessoas, o patriarcado

\footnotetext{
${ }^{13}$ Necrofeminino diz respeito ao sistema que produz a morte de mulheres. Apesar de haver os conceitos generocídio e feminicídio, que significa respectivamente a morte sistemática de um determinado gênero; o segundo é a morte de uma pessoa unicamente pela condição de ser mulher, utilizo tal termo por entender que sempre existiu um conjunto de elementos que naturaliza a morte das mulheres. Embora o conceito de "Necrofeminino" esteja sendo utilizado pela primeira vez e portanto, em construção, defendo esse conceito por se tratar de uma categoria que envolve várias situações sejam elas socioeconômicas, saúde, raciais, gêneros e religiosas. O necrofeminino tem suas bases assentadas no patriarcado na medida em que intersecciona com outras categorias. Ademais a categoria foi inspirada na ideia de "Necropolítica" de autoria do camaronês Achille Mbembe (2018).
} 
continua atual e vigoroso, desnudando realidades violentas e opressões perpetradas contra grupos considerados fora dos padrões vigentes da heteronormatividade. Dentre os quais a mulher encontra-se na condição de produtora/mãe, cuidadora, do privado, reforçando assim a divisão desigual de tarefas entre mulher e homem. As esferas social e política atuam com a valoração e diferenciação de homens e mulheres, o que nos leva a acreditar que o sistema de dominação-exploração das mulheres continua com suas engrenagens mais vivas do que nunca (SAFFIOTI, 2004).

A análise do caso revelou que as hierarquias de gênero, raça, territorialidade e religião atreladas à liderança de Mãe Obassi foram decisivas para alavancar um novo cenário para as religiões de matrizes africanas no Ceará. Mesmo que o feminicídio/assassinato tenha ocorrido pelas mãos de um homem branco, homossexual e sacerdote, este que tem sua masculinidade questionada pela masculinidade hegemônica, já que o homossexual não se enquadra nos padrões heterossexuais, logo ele também estava em defasagem. Contudo, Luiz de Xangô, por portar em seu corpo algumas características da hegemonia masculina o fez agir com a virilidade, comum à maioria dos homens cisgênero. Ele, o Babalorixá, a exibe diante de uma mulher que de alguma forma ameaça sua honra de macho, de homem provedor, inclusive das orientações religiosas. A partir disso, pode-se dizer que o patriarcado não é uma prática apenas masculina, na medida em que todos os grupos reproduzem em maior ou menor grau. Ademais, o patriarcado requer uma base que o legitime, que o revista de poder.

O peso da masculinidade religiosa que decorre das estruturas patriarcais acionou uma série de tensões nas relações e instituições religiosas de matrizes africanas, posto que na época da atuação da Mãe Obassi, tais instituições passaram a conviver com um novo modelo, quer das mudanças e acréscimos de novos elementos litúrgicos, quer da visualidade da liderança feminina. A figura máxima das religiões de matrizes africanas agora era a de uma mulher, negra e mãe solteira. Esse novo arranjo pode ter sido o ápice para que o feminicídio/assassinato ocorresse. Atrelamos ao exposto, o fato do crime ter ocorrido de forma vil, isto é dentro de um espaço religioso e mais sublime, momento em que o orixá vem à terra por meio do corpo de seus/suas filhas; mais que isso, o crime também pode ser entendido como uma tentativa de assassinato da própria divindade - Obá. Para além das perdas materiais, o episódio do feminicídio/assassinato de Mãe Obassi marca simbolicamente para sempre as religiões afro-cearenses, que "além da dor pela perda e da vergonha de ter nosso 
sagrado maculado"14.

O medo suscitado pelo episódio atingiu as demais ialorixás, posto que dentro do espectro religioso tornara-se ainda mais difícil" ser Mãe-de-Santo numa terra de homens".

A prática religiosa combinada com os dispositivos da masculinidade e da violência revelou o modus operandi do patriarcado em relação a atuação das mulheres nos espaços, estas não devem ultrapassar os limites determinados pelo macho. $O$ gênero dominante, expresso sob o cariz da masculinidade religiosa, demonstra que a raiz patriarcal constitui uma peça difícil de ser desmontada, é ela que garante a manutenção da ideologia do poder, e qualquer ameaça a esse poder pode levar à violência contra a mulher, fazendo-nos compreender que a disputa pelos espaços religiosos opera com muitos braços opressores e um deles é o necrofeminino. A masculinidade de Luiz de Xangô põe em tela sob a auréola da religião, uma feminilidade que se opõe a subalternidade, sob o manto da altivez de Mãe Obassi, uma feminilidade "farta de dádiva", cuja virilidade do referido pai-de-santo queria sujeita e disciplinada.

Porfim, esperamos ter conseguido ao longo do texto demonstrar de que maneira os espaços religiosos são terrenos férteis para as práticas das opressões/violências e, consequentemente, para a dominação masculina. Tais opressões ocorridas no candomblé do Ceará são apenas um reflexo daquilo que ocorre nos domínios mais amplos do patriarcado, aparentemente esquecido, mas vivo nas masculinidades religiosas. Em suma, para romper com as estruturas históricas da dominação masculina, urge uma força-tarefa que envolva todas as pessoas, independente do gênero, da raça, da classe e do território, para que elas sejam descontruídas na sua origem. Para tanto, conclama-se todos os segmentos sociais, a fim de destruir as bases assimétricas entre os gêneros.

\section{REFERÊNCIAS}

ALMEIDA, M. V. de. Gênero, masculinidade e poder: revendo um caso do Sul de Portugal. Anuário Antropológico. Rio de Janeiro, V.20 n. 95, 1996, p. 161-190.

AKOTIRENE, C. Interseccionalidade. São Paulo: Pólen, 2019.

BAIRROS, L. Nossos feminismos revisitados. Revista Estudos Feministas, Rio de Janeiro, v. 3, n. 2, 1995, p. 458-463.

\footnotetext{
${ }^{14}$ (Iyá Valéria de Logun Edé. Entrevista II. (abr, 2020). Entrevistador: Joanice Conceição. Fortaleza, 2021. 1 arquivo. Questionário. A entrevista na integra encontra-se digitada nos arquivos pessoais da entrevistadora
} 
BANDEIRA, L. C. Entidades africanas em "troca de águas": diáspora religiosa desde o Ceará. Dissertação (Mestrado em História Social, Programa de Pós-graduação em História) - Pontifícia Universidade Católica de São Paulo: São Paulo, 2009. Fls. 152.

BERLIN, I. Dois conceitos de liberdade: o romântico e o liberal. In: HARDY, H. (org.) As ideias políticas na era romântica. São Paulo: Cia. das Letras, 2009.

BOURDIEU, P. A dominação masculina. 3. ed. Tradução Maria Helena Kuhner. Rio de Janeiro: Bertrand do Brasil, 2010.

BRAGA, J. Candomblé da Bahia: a cidade das mulheres e dos homens. Feira de Santana: UEFS, 2014.

CARNEIRO, S. Mulher em Movimento. Revista Estudos Avançados, São Paulo, v. 17, n. 49, p. 17-49, set./dez. 2003.

CONCEICAO, J. Quando o sagrado justifica o racismo. In: CAVALCANTE, V.; CARVALHO, M. do A.; LUZ, L. C. X. Religiosidades e experiências espirituais na contemporaneidade. Teresina: EDUFPI, 2018.

CONCEICAO, J. Irmandade da Boa Morte e Culto de Babá Egum: Masculinidades, Feminilidades e Performances Negras. São Paulo: Paco Editorial, 2017.

CONCEICAO, J. Tradição sexismo e masculinidade subalternizada nas irmandades negras. In: DIAS, A.; PACHECO, A. Cláudia. Gênero, trans e multidisciplinar. Jundiaí: Paco Editorial, 2013.

CONNELL, R. W. La organización social de la masculinidad. In valdes, T. \& Olavarría, J. (eds.), Masculinidad/es: poder y crisis. Ediciones de las mujeres, v.1, n. 24., 1997, p. 31-48. Disponível em: www.cholonautas.edu.pe

FARIAS, L. L. Ogã. Obassi em memória: uma lyalorixá em terras de "homens". Entrevista estruturada com questionário. Joanice Conceição. Fortaleza: abril, 2020.

FOUCAULT. M. Microfísica do poder. Rio de Janeiro: Graal, 1979.

GEERTZ, C. A Interpretação das culturas. Rio de Janeiro: Zahar, 1989.

GIRARD. R. A Violência e a religião. São Paulo: Paz e Terra, 2008.

GONZALEZ, L. O feminismo negro no palco da história. Brasília: Fundação Banco do Brasil, 2014.

KILOMBA, G. Memórias da plantação: episódios de racismo cotidiano. Tradução Jess Oliveira. Rio de Janeiro: Cobogó, 2019. 
LANDES, R. A cidade das mulheres. Rio de Janeiro: Civilização Brasileira, 1967.

LE BRETON, D. A sociologia do corpo. Tradução Sônia M. S. Fulrmann. Petrópolis: Vozes, 2006.

LOGUM, V. Iyá. Obassi em memória: uma lyalorixá em terras de "homens". Entrevista estruturada com questionário. Joanice Conceição. Fortaleza: abril, 2020

MARTINS, C. Nós e as Mulheres dos Outros. Feminismos entre o Norte e a África. In: RIBEIRO, A., S.; RIBEIRO, M. C. Revista Geometria da Memória. Configurações pós-coloniais. Porto: Edições Afrontamento e Autores, 2016. p. 251-277.

MBEMBE, Necropolítica: biopoder, soberania, estado de exceção, política da morte. São Paulo: N-1 edições, 2018.

MISKOLCI, R. A Teoria queer e a Sociologia: o desafio de uma analítica da normalização. Sociologias, Porto Alegre: v. 11, n. 21, jun/jul, 2009, pp 150-182. Disponível em: https://www.scielo.br/pdf/soc/n21/08.pdf. Acesso em: jan. 2020

OLIVEIRA, P. P. A construção social da masculinidade. Belo Horizonte: UFMG; Rio de Janeiro: luperj, 2004.

OYĚWÙMí, Oyèrónké. Conceituando o gênero: Os fundamentos eurocêntricos dos conceitos feministas e o desafio das epistemologias africanas. In: CODESRIA Gender Series. Volume 1, Dakar, CODESRIA, 2004, p. 1-8 Tradução Juliana Araújo Lopes.

REIS, J. J. Rebelião escrava no Brasil: a história do levante dos Malês em 1835. São Paulo: Companhia das Letras, 2003.

SAFFIOTI, H. I. B. Gênero, patriarcado, violência. São Paulo: Fundação Perseu Abramo, 2004.

SAFFIOTI, H. I. B; ALMEIDA, S. S. de. Violência de gênero: poder e impotência. Rio de Janeiro: Revinter. 1995.

SCOTT, J. Gênero: uma categoria útil de análise histórica. Educação e Realidade, Porto Alegre, v. 2, n. 16, p. 5-22, jul/dez, 1995

SILVA, A. C. A desconstrução da discriminação no livro didático. In: MUNANGA, K. (Org.). Superando o racismo na escola. Brasília: Ministério da Educação/Secretaria de Educação Continuada, Alfabetização e Diversidade, 2017. p. 21-37.

SILVEIRA, R. da. 0 candomblé da Barroquinha: processo de constituição do primeiro terreiro baiano de Keto. Salvador: Maianga, 2006. 